\title{
Muslim and Democracy: A Reflection from 2012 Aceh's Gubernatorial Election
}

\author{
Irfan Iryadi $^{1}$, Mursyidin Zakaria ${ }^{2}$, Effendi Hasan ${ }^{3}$, Dedy Tabrani ${ }^{4}$, Fadhil Ilhamsyah ${ }^{5}$ \\ ${ }^{l}$ PhD Candidate at School of Law, University of Diponegoro, Semarang, Indonesia \\ ${ }^{2}$ Senior Lecturer, School of Social \& Political Sciences, University of Teuku Umar, Meulaboh, Aceh, Indonesia \\ ${ }^{3}$ Lecturer of Political Science Department, Social and Political Faculty of Syiah Kuala University, Darussalam, \\ Banda Aceh, Indonesia \\ ${ }^{4}$ PhD Candidate at Police Sciences College (PTIK) Jakarta, Indonesia \\ ${ }^{5}$ Alumnus of Political Science Department, Social and Political Faculty of Syiah Kuala University, Darussalam, \\ Banda Aceh, Indonesia \\ Irfan.aceray@gmail.com
}

\begin{abstract}
This paper explores about governor election in Aceh period 2012-2017 as a sociopolitical lesson. At that moment, political trends in Aceh are ongoing mass politics, not politics ideology based on the interests of the people. Mass politics is crewed politics on the basis of pragmatic and opportunist ideology. Intimidation and massive mobilization of the masses accompanied by money politics and imagery are characteristic of mass politics. In mass politics the potential for conflict is also quite high. Not often people who are victims. People admits that gubernatorial election of Aceh in 2012 was won by Zaini Abdullah and Muzakkir Manaf (Zikir) carried out by local political parties, namely the Party Aceh, the legislature is complete and the executive is entirely in the hands of the Party's control Aceh. All his potions and political teachings will be lowered to the service arena for Acehnese people during the 2012-2017 period. But the question then blocks in all of our minds, will the opposition be still dare to survive with the political dialectic recently? Of course we can see this at least in the first six months post the inauguration of Zikir as governor and deputy the governor of Aceh later.
\end{abstract}

Keywords: Aceh; effectiveness; democratic system; regional election.

\section{Introduction}

Aceh is the Veranda of Mecca in Southeast Asia. Election in Aceh 2012-2017 is a form of democracy to determine the elites who will rule in the Muslim region. The definition of elites here, in terms of the definition given by Mills, is those who occupy important positions in society. Or if viewed from the definition of Harold Laswell, elites are individuals who have succeeded in occupying the most important part of society because of their skills and personality traits. With these advantages, they are actively involved in the decision making process. Gubernatorial election of Aceh (Pilkada Aceh) is the arena of struggle for power between existing elites and other individuals who will then form new elites. (Rahmat Fadhil, 2012 ).

Local elections of Aceh is as a form of people's assessment of the elites. If the elite as long as they are in power is in accordance with the wishes of the people, then they will be elected again to continue the power. But if they fail, then the people will choose new elites. Actually what has a big role in giving birth to elites is the people. The good and bad of a nation and state are very dependent on the elite chosen by the people too. Political communication experts say, even though politics applies in a democratic system, it is often characterized by gross behavior. Because elites who play in the political realm do dirty things in gaining power.

Lending Harold Laswell's term, who gets what, when and how is perceived by justifying all means including imaging politics, money politics, mass mobilization, and 
intimidation to gain political support. Perhaps because of the promising politics of the loss of property, throne, position and power. Sometimes people who are well-known and democratic also follow dirty ways to win inside political competition. For some political elites, democracy is perceived as a place to fight for popular support. This is very possible, because the political trend in general is mass politics, not ideological politics based on the interests of the people, such as in 2012 Aceh's Gubernatorial Election (Hamdani Muhammad Syam, 2012).

Mass politics is politics that is awakened on the basis of pragmatic and opportunist ideologies. Massive intimidation and mass mobilization accompanied by money politics and imagery are characteristics of mass politics. In mass politics the potential for conflict is also quite high. It is not uncommon for people to become victims. Just because of different clothes, one can brush each other and mutually kill it Even more so if the elite he supports loses the election. This condition lasts almost every political event, both elections legislative, executive even in the 2012 Aceh regional elections.

The ugliest facts of the 2012 Aceh gubernatorial election (pilkada, pemilihan kepala daerah or election of local leader) are violence, intimidation, terror, threats, and destruction, so far it has become a cult which tarnishes this people's democratic party. Burning houses, burning vehicles, throwing stones, destroying props, shooting, and other acts of tyranny have become phenomena that show a graph of improvement in this period of peace and comfort. This barbarian-style democratic practice also shows that our level of political maturity in Aceh is still too primitive and ancient to interpret this five-year folk party.

At least this is a turning point in the history of Aceh's journey that is not going forward, but backward, aka backward. Even if the people of Aceh all, both successful teams, candidate pairs, and other communities do not want to rise up against these forms of tyranny, then the tyranny will continue to run rampantly. And we then leave black historical records for our next generation. A poem of struggle states that 'fight against evil, so goodness dominates life'.

However, the Aceh problem is too complex and difficult to be solved by the Acehnese. It takes a lot of heads, ideas, hands and ideas so that a great narrative of the future can be built. Being an area that is baldatun thayyibatun wa rabbun ghaffur (a just and prosperous country that is in God's forgiveness) - who always wants to acknowledge and learn from mistakes and be better in the future and always eager to help each other - help in kindness.

Therefore, the affairs of the "top meu top" (vote or not to vote) tend to cause social conflict and chaos in the community, especially until the disappearance of human lives without any sense of humanity. In the Acehnese society there was a lot of discourse about: Pakoen neutop? (Why I choose that one?), Peu di top? (What was voted?), Soe kutop (Who did I vote?), Nyoe kutop (this is I vote). It is the right of the community to determine what is good and logical according to their own understanding. is the freedom of conscience to make choices with the ideals and expectations desired by the voters.

As socio-political lessons, we try to analyze the effectiveness of democratic system and its obstacles during Aceh regional election for governor and vice governor of Aceh in 2012. It employed descriptive-qualitative methodology, which attempted to unfold the real condition comprehensively. The data was collected both from library and also field research.

Library resources were articles, books, documents, and also previous related researches, meanwhile field data were in-depth interview and observation. To determine the sampling, this research used purposive sampling technique, in which selected resource people were 
considered to be trusted and possessed a depth knowledge related to the research. The total number of sample was 36 informants consisted of 15 people from two sub-districts and 1 city, which were West Aceh, Pidie Jaya, and Banda Aceh, 8 informants were from regional election committee, three informants from the candidate of governor and vice governor, two person from Aceh Government and Parliament House of Aceh, three person from political parties joining regional election, and 5 person from Civil Service Organization and observer.

The result illustrates that Regional Election for Governor and Vice Governor of Aceh in 2012 was merely success in procedural context, yet not substantially. The inconsistency of legal basis for regional election, the repeated rescheduling of the election agenda, violence, intimidation, money politics and also lack of socialization about the Regional Election were contributing factors to the failure.

\section{Review of Literature}

\subsection{Democracy Theory as the Basis for Regional Election}

Etymologically, the word "democracy" was derived from Greek language namely "demos" which means people or citizen in an area, and "cratein" or "cratos" meaning "power" or "sovereign". Consequently Demos Cratein or Demos Cratos is a condition in which state's power relies on the people and the highest power is on people's decision. People is the sovereign, ruled by people (Azyumardi Azra, 2000: 110).

Terminologically, Joseph A. suggests that democracy is an institutional action to reach political decision in which every individual has the right to decide a competitive methodology upon people's voice. Sidney Hook asserts that democracy is state, which its important policy was derived directly or indirectly from majority covenant delivered freely. Phillippe C. Schmiller and Terry Linn Karl declare that democracy is governmental system, which government must present its responsible for its action to public or citizen through cooperation or competition with people's representative. (Azyumardi Azra, 2000: 110-111).

From the above opinion, it is possible to draw two concepts of democracy. First is decentralization. Etymologically decentralization is derived from "de" and "centerum". "De" means to remove, move away from, or to let go as used in de-colonization, debureaucratization, etc. The word "Centerum" means central or to centralize power in the capital of a state, consequently decentralization is a action to move away or fade away, to let go from central (Koesoema Atmadja, 1979: 14). This means that the power to rule is not only from the central government yet is also from lower institutional level either under the same territory or the same functional institution. The lower institutions are allowed to manage and arrange its own mandatory task as part of central government (Philipus M. Hadjon, 2008; 111).

Decentralization has two perspectives namely administration and also politic. Administratively, decentralization is defined as the transfer of administrative responsibility from central to local government. Politically, decentralization is a transfer of power, from to level to lower level, in a territorial hierarchy, which could be one of government within a state, or office within a large organization. (Eko Prasojo, et al., 2006: 32).

Political decentralization is commonly related to democratization, which means people are involved indirectly or directly in every state's policy making through the House of Parliament. Basically democratization suggests the changing process to strengthen the sovereign of people as according to democratic value. Democratization also can be defined as 
a process to a more democratic action, signed by the ending of authoritarian realm, constructing a democratic realm and the occurrence democratic realm's consolidation (TB. Massa Djafar, 2008: 196).

The second perspective is local democratization. This is an implication of decentralization run by local government as the epitome of democracy system in Indonesia. The main concept is to involve citizen through a consensus process to accomplish together objectives. In Indonesia, local democracy is a subsystem of democracy for local government to develop a mutual relationship with its subject within the territory. Consequently, the governor, the legislative representation and also the citizen will have opportunities to formulate and implement the fittest policies needed by the local citizen (Deden Faturohman, 2005: 2).

\subsection{Aceh Election}

The direct regional election in Aceh is the embodiment of 1.2.1, 1.2.2 and 1.2.3 points of the reconciliation agreement stated in Memorandum of Understanding between Indonesia Government and Aceh Freedom Movement. Following the bill No. 11 year 2006 about Aceh Government, therefore, all election including Governor, vice governor, Mayor and vice mayor, regent and vice regent has been executed for two times already.

In the first regional election in 2006, Drh. Irwandi Yusuf, M.Sc and Muhammad Nazar, S.Ag won the run attaining 768.745 votes $(38,2 \%)$. The elected governor, Drh. Irwandi represented GAM elite while Muhammad Nazar was a former Aceh Referendum prominent figure from Sentral Informasi Referendum Aceh (Aceh Referendum Information Center) (Rusdiono Mukri and Mujiyanto, 2009:356). The second regional election first schedule was in the end of 2011. However, due to many occurring problems, Constitutional Court demanded Independent Election Commission (KIP) to reschedule the election date four times from December 24 2011 to April $9^{\text {th }} 2012$ (Askalani, et al., 2012: 14). For this election, dr. Zaini Abdullah and Muzakkir Manaf (ZIKIR) from Aceh Party won by gathering 1.327.695 voters $(55,75 \%)$ (Askalani, et al., 2012: 106)

Regarding the 2012 election, there were many speculations that the 2012 election would run well with honesty, and justice. Nonetheless the reality spoke differently as there were many negative findings contributing to disabilities of democratic system in Aceh, one of them was money politic.

Money politic may take form in distributing money for campaign participants during the mass campaign period, the tranquil week and also in the morning of the Election Day (Aceh Panwaslu data, 2012). In addition to that, a more concerning issue was intimidation and violence occurring from 2010 until 2013. According to Sistem Nasional Pemantauan Kekerasan (National Violence Monitoring System), there were 200 violent cases, which related to Regional Election in Aceh. From the 200 cases, seven were dead, 103 people were injured, and 29 units of building were damaged (www.snpk-indonesia.com, accessed on July $16^{\text {th }}$ 2013). The Election Monitoring Committee also claimed that 37 of it were administration infringement and crime, which was found during campaign period.

While there were also 57 cases of violence and intimation occurred near to the voting day (Askhalani, et al., 2012: 82). Additionally, the non-voter number in 2012 was increased comparing to 2006. There were only 2.380 .386 voters out of 3.244 .729 permanent voters list were licit, while 864.343 or 26.6 percent were counted as non-voters or broken vote. In 2006, the non-voter number was $528.196(20,06 \%)$ from 2.632 .935 permanent voters list (Data of 
KIP Aceh, 2012). Therefore, it is important to execute this research in order to find out the effectiveness of democratic system embodiment and its obstacles within the direct regional election for Governor and Vice Governor of Aceh in 2012.

\section{The Research Result and Analysis}

\subsection{The Implementation of Regional Election of 2012 in Aceh.}

The Aceh Regional Election in 2012 was the second election event after Aceh Peace and Reconciliation. The event supposed to happen in 2011 Due to the occurrence of many concerning issues, however, the election committee delayed it until April $9^{\text {th }}$ 2012. There were five couples that run for the election. Three of the candidate came from independent candidacy. They are Teungku Haji Ahmad Tajuddin and Ir. Haji Teuku Suriansyah, M.Si as the first candidate, drh. Irwandi Yusuf, M.Sc and Dr. Ir. Muhyan Yunan, M.Sc as candidate number two, and Prof. Darni M. Daud, M.A and Dr. Ahmad Fauzi, M.Ag were chosen as candidate number three. Mean while, the other two candidates run as Parties' representative, namely candidate number four; Muhammad Nazar, S.Ag, and Ir. Nova Iriansyah, MT from parties' coalition including Democrat Party, Unity and Development Party (PPP) and SIRA Party and candidate number five; dr. H. Zaini Abdullah and Muzakir Manaf from Aceh Party (KIP Aceh, 2012)

From procedural point of view, the Regional Election in 2012 was considered successful, because Independent Election Committee (KIP) of Aceh conducted the election phase correctly according to regulation ${ }^{1}$. According to Abdullah Saleh, the 2012 Regional Election in Aceh was proceed democratically, because the election committee opened opportunities to various type of candidate including from Independent fraction. Moreover, the regional election became more democratic also because there was no candidate from the current ruling incumbent. Hence citizen's decision to vote would not be influenced by the running program held by the incumbent ${ }^{2}$.

Consequently, the couple that won the election certainly was the citizen's choice as according to democratic value. As compiled by KIP Aceh, following is the recapitulation of regional election result in 2012:

Table 1. Election Result

\begin{tabular}{|l|l|c|c|l|}
\hline No. & \multicolumn{1}{|c|}{ Candidate's name } & Poll & \% & \multicolumn{1}{|c|}{ Candidacy } \\
\hline 1 & $\begin{array}{l}\text { Teungku Ahmad Tajuddin } \\
\text { Ir. Suriansyah, M.Si }\end{array}$ & 79.330 & 3,33 & Independent \\
\hline 2 & $\begin{array}{l}\text { Drh. Irwandi Yusuf, M.Sc } \\
\text { Dr. Muhyan Yunan,M.Sc }\end{array}$ & 694.515 & 29,18 & Independent \\
\hline 3 & $\begin{array}{l}\text { Prof.Darni M Daud, MA } \\
\text { Dr. Ahmad Fauzi, M.Ag }\end{array}$ & 96.767 & 4,07 & Independent \\
\hline 4 & $\begin{array}{l}\text { Muhammad Nazar, S.Ag } \\
\text { Ir. Nova Iriansyah, MT }\end{array}$ & 182.079 & 7,65 & $\begin{array}{l}\text { Demokrat Party, } \\
\text { PPP, SIRA Party }\end{array}$ \\
\hline
\end{tabular}

${ }^{1}$ Kamaruddin Andalah, Chairman of Bureaucracy, interview, 22 November 2013 and Salamuddin, Citizen of West Aceh, interview, 30 October 2013.

${ }^{2}$ Abdullah Saleh, Chairman of Legislation Office and Member of Commission A of Aceh House of Parliament, interview, 18 November 2013. 


\begin{tabular}{|l|l|l|l|l|}
\hline 5 & $\begin{array}{l}\text { dr. H. Zaini Abdullah } \\
\text { Muzakir Manaf }\end{array}$ & 1.327 .695 & 55,78 & Aceh Party \\
\hline
\end{tabular}

Source KIP Aceh, 2012

The table shows that candidate number 5 dr. H. Zaini Abdullah and Muzakir Manaf gained the most vote, which are 1.327 .695 (55,78\%). Consequently the Regional Election Committee declared the couple as the elected governor and vice governor through plenum and the Home Affairs Minister, Gamawan Fauzi, inaugurated them on 25th June 2012 in Special Plenary Session of the House of Representatives of Aceh for the term 2012-2017 (KIP Aceh, 2012).

Moreover, Acehnese political participation in regional election in 2012 displayed higher number comparing to other provinces in Indonesia. Also, opportunities for Acehnese to involve directly as governor's candidate in 2012 was opened wider than previous election in 2006, which the governor candidate was merely available for those who came from national political parties and independent candidacy. Meanwhile in 2012, the candidate was not only opened for national political parties and independent candidacy but also for local political parties.

Nonetheless, unfortunately regional election in 2012 had concerning obstacles. The bill no. 11 year 2006 about Aceh Government collided with the bill no. 32 year 2004 about local government. This caused the endorsement of Aceh amandement regarding the regional election had to be postponed for 4 times by KIP (Independent Election Commission) as instructed by Constitutional Court. Besides, intimidation, kidnaping, fights and murder before and during the campaign season had destructed the democracy of Regional election ${ }^{3}$.

\subsection{The 2012 Regional Election in Aceh was not yet operated as according to democratic values.}

There were still many shortcomings during the regional election in Aceh, such as the indifferent of legal basis and the rescheduling of regional election, intimidation, violence and money politic, which instigated the Aceh regional election substantially foiled according to democratic value. The flaws were:

\section{a. The Indifferent of Legal Basis and Rescheduling of Regional Election}

The article of 256 number 11 year 2006 stated that independent candidate was only allowed to join election after the law no. 11 year 2006 on Aceh Government was approved and only for regional election in 2006. This regulation was certainly absurd, because Aceh Government, which was the initiator of independent candidate's policy in Indonesian democracy system, was allowed to have independent candidate only for one election.

Meanwhile in national level, the independent candidate was legal to join in every regional election in Indonesia. This uncertainty about the regional election in 2012 was instigated by the Constitution Court's decision no. 35/PUU-VII/2010 dated December $30^{\text {th }}$ 2010 about the revocation of Article 256 number 11 year 2006 about Aceh Government. The

${ }^{3}$ Regional Election Supervisor, Interview, 12 November 2013, Muhammad Alminto, Team SucessSeuramoeIrwandi-Muhyan, Interview via email, 28 November 2013 and Faisal Ridha, Team Success Muhammad Nazar-Nova Iriansyah, interview, 23 November 2013). 
consequence was The Independent Election Commission (KIP) had to revoke the article 256 no. 11 year 2006 hence rescheduling regional election date and stages also must be done. ${ }^{4}$

The KIP revocation, which was based on Aceh regulation no. 7 year 2006, was conducted because Aceh Government and Aceh House of Parliament did not discuss Aceh new regulation for regional election. However, Aceh Party and also Aceh House of Parliament rejected KIP Aceh's action using the law no. 7 year 2006 as the legal basis. They believed that KIP Aceh's action to accommodate Independent candidate was against with Aceh Government Bill. Constitutional Court's decision to repeal article no. 256 of Aceh Government Law was the act of rifling through the rights of Acehnese which has been set in Aceh Law, hence KIP action to accommodate independent candidate was a mistake ${ }^{5}$.

The repeal made by Aceh Party and Aceh House of Parliament caused uncertainty on the law basis. Therefore, KIP Aceh had to reschedule the regional election for four times. The alteration, was not only instigated by arguments of legal basis or regional election's regulation between KIP Aceh, Aceh Government and Aceh House of Parliament, but also because there was an agreement to "cooling down" (pause) instructed by Home Ministry. Additionally, Constitutional Court also demanded KIP to reopen candidate's registration to accommodate all political element in Aceh and reschedule the election date ${ }^{6}$, as explained below:

Table 2. Election Rescheduling

\begin{tabular}{|c|l|l|}
\hline KIP Aceh Decision & Election Schedule & \multicolumn{1}{c|}{ Reason of Rescheduling } \\
\hline No. 1 Year 2011 & 14 November 2011 & $\begin{array}{l}\text { This timetable was changed owing to a } \\
\text { "cooling down" agreement facilitated by } \\
\text { Home Minister. }\end{array}$ \\
\hline No. 17 year 2011 & 24 December 2011 & $\begin{array}{l}\text { This schedule change because of the } \\
\text { injunction of Constitutional Court (MK) } \\
\text { related to a petition of Khalid to sue KIP } \\
\text { Aceh for not allowing him to register as } \\
\text { candidate due to the very short time of } \\
\text { registration. The injunction ordered KIP } \\
\text { Aceh to reopen enrolment for a week. }\end{array}$ \\
\hline No. 26 year 2011 & 16 February 2012 & $\begin{array}{l}\text { This schedule was changed again because } \\
\text { of the interim decision of the } \\
\text { Constitutional Court (MK) related to } \\
\text { lawsuit against Home Minister KIP Aceh. } \\
\text { Home Minister demanding postponement } \\
\text { of Aceh Election in respect of the } \\
\text { political chaotic. The Constitutional }\end{array}$ \\
\hline
\end{tabular}

\footnotetext{
${ }^{4}$ Interview with Chairul Fahmi, Executive Director of The Aceh Institute, and Muhammmad, Komisioner KIP, Interview, 12 November 2013 and 31 October 2013.

${ }^{5}$ FachrulRazi, Aceh Party Speaker, interview via Email, 28 November 2013.

${ }^{6}$ Munawarsyah, Chairman of KIP Banda Aceh, Interview, 18 November 2013, BahagiaIdris, Chairman of KIP Aceh Barat, Interview, 31 October 2013, dan Firmansyah, Commissioner of KIP Pidie Jaya, Interview, 29 November 2013.
} 


\begin{tabular}{|l|l|l|}
\hline & & $\begin{array}{l}\text { Court (MK) rejected the claim and the } \\
\text { interim decision of the Constitutional } \\
\text { Court (MK) ordered KIP Aceh to reopen } \\
\text { the registration period for a week and to } \\
\text { implement the Regional Election at the } \\
\text { latest on 9 April 2012 }\end{array}$ \\
\hline No.31 year 2012 & 9 April 2012 & Election Day Voting \\
\hline
\end{tabular}

Source: Report of the Aceh Monitoring in 2012 Regional Election.

\section{b. Intimidations and Violence}

Implementation of Aceh Election in 2012 was expected to be peaceful and executed without intimidation as a pledge of peace by 5 (five) pair Candidates for Governor and Deputy Governor on March 14, 2012 in the courtyard of the Grand Mosque Baiturrahman. The Election Pledge Peace announcement was witnessed also by a number of United Indonesia Cabinet Minister Volume II, Member of Parliament from Aceh and the Acehnese senator. The candidates agreed to create a peaceful Regional Election, free of intimidation and violence

However the implementation of elections in Aceh in 2012 had taken at least more or less were 108 cases of intimidation and violence. Of the 108 cases of intimidation and violence, the majority of cases were related to the election of Governor and Vice Governor of Aceh. The violence occurred in various kinds ranging from small-scale things like the destruction of the props in the form of campaign billboards and posters, sending short messages (SMS) to any threatening actions such as large-scale fights, shootings, kidnappings and car burning of certain campaign team. The security or police had not disclosed most of the violence ${ }^{7}$.

Shooting incidents occurred against Asnawi Abdul Rahman, member of Team Success of pair candidates, Yusuf and Muhyan Yunan in East Aceh. On February 5 ${ }^{\text {th }}, 2012$ at 20:30 $\mathrm{pm}$, his house was shot several times by unknown person from the direction of the highway. Witnesses saw the culprit as many as four young men with faces covered with black clothe that came from the north by two motorcycles. This incident caused no casualties, police found three bullet points of $\mathrm{AK}-47$ and a pistol grain projectile ${ }^{8}$. Intimidation was also happened in the implementation of the Regional Election in 2012, such as intimidation of the organizers, community and inters Success Team of Candidates for Governor and Deputy Governor. Threat occurred in the form of a direct threat or threats by phone or through the sending of short message service (SMS). The threat was not only the case for the individual organizers, community, and Success Team of Candidates but also to the families concerned ${ }^{9}$.

Likewise, the practice of intimidation and violence that occurred during the preparation, the campaign, and on election day of the Regional Election in 2012 was more prominent to the existence of disputes between supporters of Candidates of Irwandi Yusuf and Muhyan Yunan advancing through independent candidates than supporters of dr. Zaini Abdullah and Muzakir Manaf from Aceh Party. This dispute aroused because of the conflict between

\footnotetext{
${ }^{7}$ ChairulFahmi, Executive Director of The Aceh Institute, Interview, 12 November 2013 and Asqalani, Chairman of Bawaslu Aceh, Interview, 16 November 2013).

${ }^{8}$ ChairulFahmi, Executive Director of The Aceh Institute, Interview, 12 November 2013.

${ }^{9}$ Rosni Idham, Former Chairman of Panwaslu Aceh Barat, Interview, 4 November 2013.
} 
Irwandi Yusuf associated with the elites of Aceh Party regarding independent candidate existence and the candidacy of Irwandi Yusuf as Governor of Aceh for period 2012-2017.

\section{c. Money Politics}

Implementation of Regional Election for Governor and Deputy Governor in 2012 in Aceh was still involving the practice of money politic although the evidence was still difficult to reach. The practice of money politics was mostly done by the incumbent couples (Governor and Deputy Governor are still serving). They used the money politics indirectly. The practice of money politics was conducted in the form of promises of social grants to the community. Based on the study findings, citizen were requested to write proposal by the working group of Governor and vice governor then give it to them to attract funds and social assistance budget from Aceh government. This practice was not revealed directly by the Supervisory Committee and the Independent Election Commission (KIP), but what matters was the budget would be given when regional election was about to begun ${ }^{10}$.

The practice of money politics was going on with various motifs, either cash or in-kind of provision of groceries, which was not given directly by the candidates for governor and vice governor or a candidate's campaign team but made by public figures trusted by the candidate and their Success Team. Community leaders, who did the action, admitted that he was only giving alms to his brothers who were less capable and no relation to the Regional Election of Governor and Deputy Governor. Thereby such motif made the practice of money politics was difficult to unfold ${ }^{11}$.

The practice of money politics was also happening at polling stations (TPS) conducted by the Team Success. They action was done by giving envelopes containing money to voters. Generally, the public knew such an event but people just let the action without reporting to the Supervisory Committee (Panwaslu). The practice of money politics was also held in private as giving cash or giving food for the recipient before the Election Day, so that this kind of practice was difficult to prove. Proof of this practice can only be known after the completion of the Regional Election took place. In addition, lack of awareness of the public to report the practice of money politics made it difficult for Supervisory Committee to trace evidence.

However, the level of practice of money politics in the Regional Election of Governor and Vice Governor of Aceh in 2012 was still low, because the fraud occurred more prominent in the practice of intimidation and violence. The report about money politic to Supervisory Committee was still low. Therefore the practice of money politics can be said to be not significantly affect the implementation of the Regional Election of Governor and Vice Governor of Aceh in 2012. The practice frequently occurred during the campaign and at the dawn of voting day.

\section{Conclusion}

\footnotetext{
${ }^{10}$ Risman A Rahman's perspective, Golkar Party's Member of DPD I Aceh, Interview, 10 November 2013, a same perspective was also delivered by Naidi Faisal, Aceh Political Analyst, Interview, 7 November 2013.

${ }^{11}$ Tgk Helmi, Citizen of Aceh Barat, Interview, 1 November 2013 and Almufarid, citizen of Banda Aceh, interview, 23 November 2013.
} 
From the research, it can be concluded that the implementation of the General Election of Governor and Vice Governor of Aceh in 2012 was not fully been effective in accordance with democratic values. The implementation of regional election in 2012 was success only in procedural perspective yet failed substantially. This was due to the uncertainty about the legal basis of the election, the repeated schedule shifts, many intimidation and violence, money politics and lack of socialization of the importance of the meaning of the Regional Election. Looking at the facts on the ground and based on the research results of this study, there are some recommendations as following:

First, the need for synchronization of the legal basis of Aceh Election between general and specific rules the implementation of the General Election. Consequently, the Election schedule can run on time.

Second, Election organizers such as Election Supervisory Committee (Panwaslu) and the Independent Election Commission (KIP) should tighten the rules in the Regional Election campaign and provide tough sanctions for violations occurred in every Regional Election.

Third, the need for strict yet applicable regulations and as well as raising public awareness to reject the practice of money politics carried out by the candidate and Success Team. The public should not only think about short-term profit without realizing the impact of bad practice of money politics in the future.

Fourth, it is essential to evaluate the weaknesses in the implementation of the Election's system in Aceh and to find the best solution to these problems so that the Election in Aceh can be accomplished in accordance with democratic values.

\section{References}

Abdul Muluk Lubis. (2009). Calon Independen Dalam Pemilihan Kepala Daerah Di Tinjau dari Undang-Undang Pemerintah Daerah. Skripsi. Universitas Sumatera Utara.

Ahmadi, Rulam. (2005). Memahami Penelitian Kualitatif. Malang: UM Press.

Ali, Sayuthi M. (2002). MetodologiPenelitian Agama Pendekatan Teori dan Praktek. Jakarta: PT Raja GrafindoPersada.

Askhalani, et al. (2012). Rekam Jejak Demokrasi Aceh. Banda Aceh: GeRAK Aceh and Yayasan TIFA.

Azra, Azyumardi. (2000). Demokrasi, Hak Asasi Manusia \& Masyarakat Madani. Jakarta: Prenada Media.

Data of Election Supervisor Commission (PANWASLU) Aceh year 2012.

Data of Independent Election Commission (KIP) Aceh year 2012.

Deden, Faturohman. (2005). "Demokrasi Lokal Dalam PemilihanKepala Daerah Langsung di Indonesia" JurnalImiahHukum. Vol 13 No.3.

Eko Prasojo, et al. (2006). Desentralisasi dan Pemerintahan Daerah: Antara Model Demokrasi Lokal dan Efisiensi Struktural. Depok: DIA FISIP UI.

Hamdani Muhammad Syam. (2012). Elit dan Demokrasi Dalam Perspektif Komunikasi Politik, pengantar untuk buku Kadalisasi Pilkada Aceh, Sebuah Catatan, Banda Aceh: Penerbit Stigma.

Koesoemahatmadja. (1979). Pengantar Ke Sistem Pemerintah Daerah Di Indonesia. Bandung: Binacipta.

M. Ikhsan, Artikel :Evaluasi Pelaksanaan Pemilihan Kepala Daerah Secara Langsung di 
Kabupaten/Kota, from : http://www.scribd.com/doc/26366356/Artikel-m-IkhsanEvaluasi-Pelaksanaan-Pemilihan-Kepala-Daerah-Kabupaten-Kota.

Philipus M. Hadjon. (2008). Pengantar Hukum Admistrasi Indonesia. Yogyakarta: Gadjah Mada University Press.

Rahmat, Fadhil. (2012). Kadalisasi Pilkada Aceh, Sebuah Catatan, Banda Aceh: Penerbit Stigma.

Reports of Aceh Regional Election's watch, The Aceh Institute, 2012.

Strauss, Anselm and Juliet Corbin. (1990). Basic of Qualitative Research: Grounded Theory, Prosedures, and Techniques. New Delhi: Sage Publications, Inc.

TB. Massa Djafar. (2008). "Pilkada dan Demokrasi Konsosional di Aceh". Jurnal Poelitik.Vol. IV No.I.

Tri Wibowo, Agung et al. (2009). "Pilkada dan Demokratisasi Lokal Studi Kasus : Pemilihan Kepala Daerah di Jawa Timur Periode 2008-2013". Paper. FISIP Universitas Indonesia. www.snpk-indonesia.com accessed on 16 July 2013 at 08.40 p.m. 